plain on these issues after reviewing the evidence available. Although he concludes that whales are not intelligent in any special sense, he believes this is no reason to excuse the sorry way in which man has treated the whales. The history of whaling and the future for whales which he describes do not lead him to an over-optimistic conclusion. But this book by its clarity of presentation and usefulness as a major source for all the most important references on its subject could well influence that outcome by its level-headed approach.

RAY GAMBELL

\title{
The Desert Bighorn, edited by G. Monson and L. Sumner. Arizona UP, Tucson, \$14.95.
}

Although the description on the cover of this book implies that it is directed towards the game hunter it is in fact a collection of serious studies on the desert bighorn by 15 naturalists and biologists, and one archaeologist. Perhaps it will not hold the attention of the reader with the charm of Valerius Geist writing of his own fieldwork on the same wild sheep, Ovis canadensis. It does, however, contain much valuable information on behaviour, relationships with man and other pedators, habitat preferences, physiology, and population dynamics.

The book is dedicated to Charles Hansen, who was killed in an aeroplane accident in 1973. He had helped to plan the contents from the early 1960 s as a product of the Desert Bighorn Council, and nine of the 22 chapters were written either jointly or entirely by him. It is therefore not as up-to-date, especially the bibliography, as might be expected of a book published in 1980; nevertheless it should prove essential reading for anyone interested in the history of wild sheep in North America and their conservation today. The archaeological evidence for the hunting of bighorn sheep in the past is discussed by Campbell Grant, while the justification for its continuance today is presented by W.E. Kelly. Controlled hunting may not reduce the numbers of sheep directly, but a more insidious problem is the harmful effect of altering the ram-ewe proportions that is the result of modern hunting for trophy heads, as predicted by Geist and others. If, as Monson estimates, there is a total population of around 20,000 desert bighorn in the USA (1978 figures), this question should receive very careful monitoring.

JULIET CLUTTON-BROCK

\section{Animal Suffering; the science of animal welfare, by Marian Stamp Dawkins. Chapman, $£ 3.95$.}

Pain and suffering are positively an advantage to animals in teaching them what to avoid if they are to survive. Animals in cages, however, may not escape from such adverse experiences. What is more, we may not know what is adverse when we see it. It now seems, for instance, that separating a sheep from its herd (e.g. for shearing) is far more traumatic for it than marching the sheep plus friends into a slaughterhouse. Dr Dawkins, then, is here concerned with how to recognise mental suffering.

The fundamental problem is that, all too often, we measure animal discomfort by uninformed analogy with ourselves. Yet, as Dawkins points out, the essential differences between ourselves and other species make analogy hazardous; we would not choose to live the inverted, insectivorous life of a bat or the peptic existence of a tapeworm (to quote one of her extreme examples). So she has analysed the ways of evaluating animal suffering, and the best clues turn out to be behaviour, apparent physical health, the animal's preference, and, if it can be measured without causing suffering, physiological change.

It is a complex issue, pocked with emotionalism, misinterpretation, anthropomorphism and inadequate research, but Dawkins beats them all out and points out the pitfalls. Sometimes she beats too hard. Thus, for example, productivity as a sign of well-being is written off because to some people this means productivity of a farm rather than a single 
animal. And the chapter comparing wild with captive animals, although superbly well argued, quite fails to consider captive wild animals. Even so, the book is an outstanding contribution to its subject.

You cannot have direct evidence of the subjective experience of any other being. In the end, to identify animal suffering you have to do a lot of research, take clues from health, physiology and behaviour, and then guess.

JON BARZDO

\section{Survival in the Wild, by Cindy Buxton. Collins, $£ 5.95$.}

What a debt the conservation movement owes to the wildlife photographers - coupled of course with the inventors of colour television! Their beautiful and often amazing films have opened up a new world for millions of people, and made conservationists of them, whether they realise it or not. Cindy Buxton is one of the many talented photographers who have been prepared to spend weeks and months camping in deserts, sloshing through swamps, cooped up in a sun-baked hide (where the temperature can reach an amazing $120^{\circ} \mathrm{F}$ ) or camping at $14,000 \mathrm{ft}$ in the mountains. She describes it all in a humorous self-deprecatory way, but there is no doubt of her steel and her ability to cope with problems that are inevitable -like the occasion in Kenya when the python she was filming slithered under her car and wrapped itself round the engine for extra warmth - it took her two hours of hard struggle flat on her back to unwind him - or the much worse occasion when the self-starter packed up and she had to wade three miles, rifle on shoulder, certain that 'crocs were watching our every movement', and at one point sank into a bog - fortunately only up to her neck. But the consolations, of course, for the Cindy Buxtons of this world are in the satisfaction of working in wild places and the chance of entering to some degree into the world of their subjects. After you have watched unseen, from the privacy of a hide, a malachite kingfisher or a shoebill stork right through its nesting period - and Cindy took her opportunities to make copious notes as well as films, particularly of the shoebills - you have some understanding of their world. And so perhaps have those important TV viewers.

MAISIE FITTER

Backpacking in Chile and Argentina plus the Falkland Islands, by Hilary Bradt and John Pilkington (Bradt Enterprises, \$3.95, and \$6.95) is packed with information and illustrations, much of it of value to the armchair traveller and those who use wheeled and winged vehicles for their travel as well as those who go on foot. (41 Nortoft Road, Chalfont St. Peter, SL9 0LA.)

Rivers, Lakes and Marshes (OUP, £5.50) is half an illustrated (colour) field guide to a good selection of the commoner wetland species by a team of authors, and half an 'ecological essay' on these habitats by Brian Whitton.

An Illustrated Guide to River Phytoplankton, by Hilary Belcher and Erica Swale, is a well laid-out and illustrated (black and white drawings) identification paperback published by HMSO for the Institute of Terrestrial Ecology $(£ 1.50)$.

Birds of Australia, by Pat and Peter Slater, in Warne's Observer series ( $£ 1.95)$ features 150 species (covering all families), all illustrated, mostly with colour photographs. In the same series is a revised edition of John Cleggs valuable Pond Life $(£ 1.80)$.

The biology and conservation problems of the Pigmy Hog and the Hispid Hare are examined in Special Scientific Report No. 1 of the Jersey Wildlife Preservation Trust by William Oliver based on his field research. 